\title{
Costilla cervical articulada con primera costilla como causa de isquemia aguda
}

\section{Cervical rib articulated with first rib as a cause of acute ischemia}

\author{
Emiliano Cano-Trigueros ${ }^{1,2}$ y Romina Díaz-Serrano ${ }^{1}$
}

Varón de 43 años que consulta por dolor en reposo, parestesias y frialdad en mano derecha sin síntomas preexistentes.

Exploración física: pulso subclavio y ausencia del resto. Estudio cardiológico normal. El angio-TC 3D muestra costillacervical articulada con primera costilla (Figura 1A-C), arteria subclavia con dilatación postestenótica y obstrucción de arteria humeral (Figura 1B y C). Con el diagnóstico de isquemia aguda del miembro superior derecho por obstrucción humeral de etiología tromboembólica se indicó cirugía, realizando escalenectomía, liberación del plexo braquial, resección de la costilla cervical, injerto subclavio-axilar con PTFE (Figura 2) y tromboembolectomía humeral y distal. El paciente fue dado de alta a las $72 \mathrm{~h}$ con pulsos distales y sin complicaciones. El síndrome del desfiladero torácico es la compresión del plexo braquial o de la arteria y vena subclavia a la salida del tórax. La clínica arterial es rara, sobre todo la aguda, y se produce por compresión de la arteria subclavia, provocando dilatación de la misma, daño intimal y la consecuente trombosis arterial y embolización distal ${ }^{1}$. Ante isquemia aguda de la extremidad superior en paciente joven hay que descartar anomalías óseas que originen la misma en el contexto del síndrome del desfiladero torácico ${ }^{2}$.
'Servicio de Angiologia y Cirugia Vascular, Hospital Universitario Morales Meseguer, Murcia, España. 2Departamento de Cirugia, Facultad de Medicina Universidad de Murcia, Murcia, España.

Recibido el 9 de marzo de 2017, aceptado el 30 de marzo de 2017.

Correspondencia a: Emiliano Cano-Trigueros emilianocanotrigueros@ gmail.com

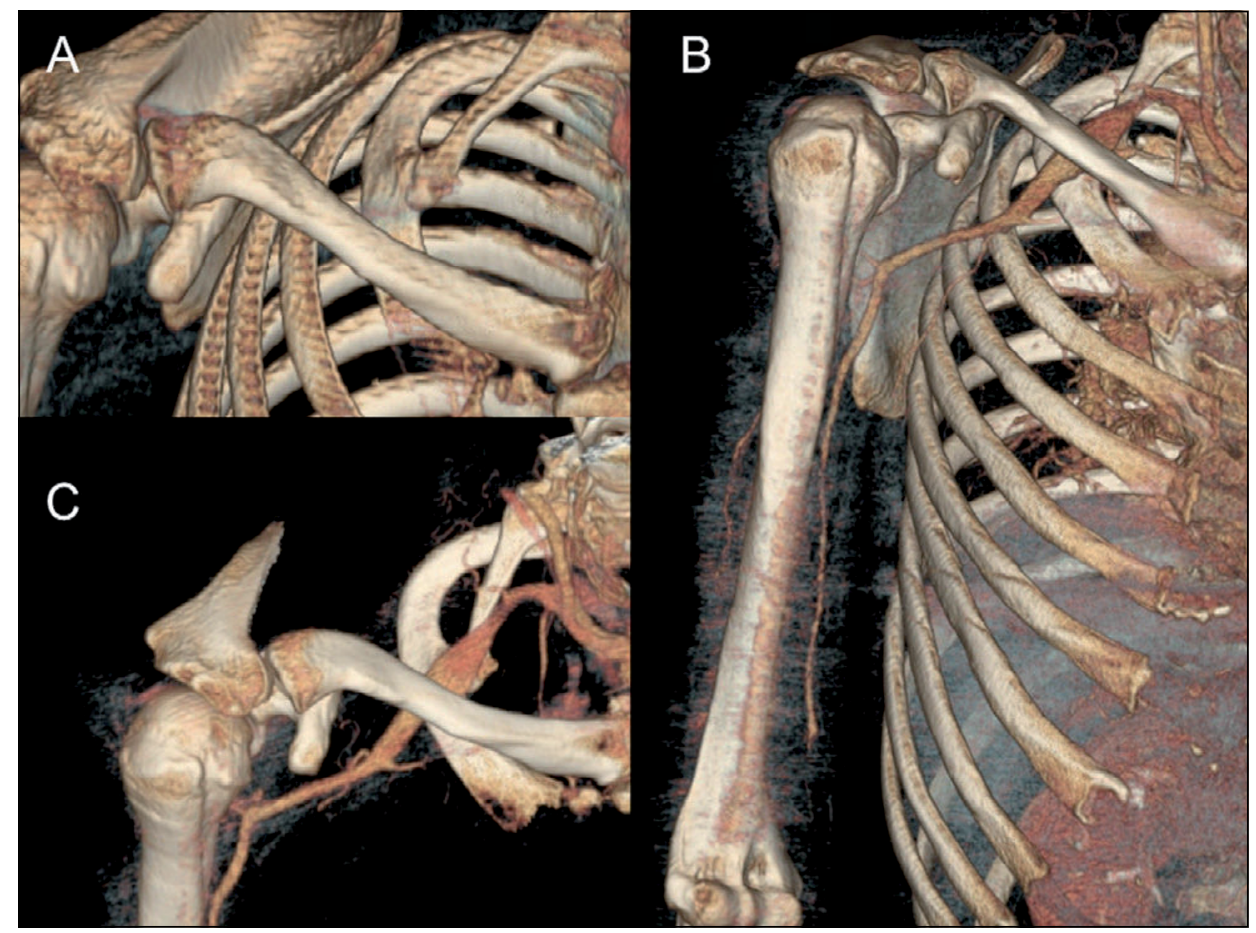

Figura 1. Angio-TC 3D. A) Detalle de articulación de costilla cervical con 1 costilla. B) Obstrucción de arteria humeral. C) Costilla cervical, dilatación postestenótica de arteria subclavia. 


\section{IMÁGENES Y CIRUGÍA}

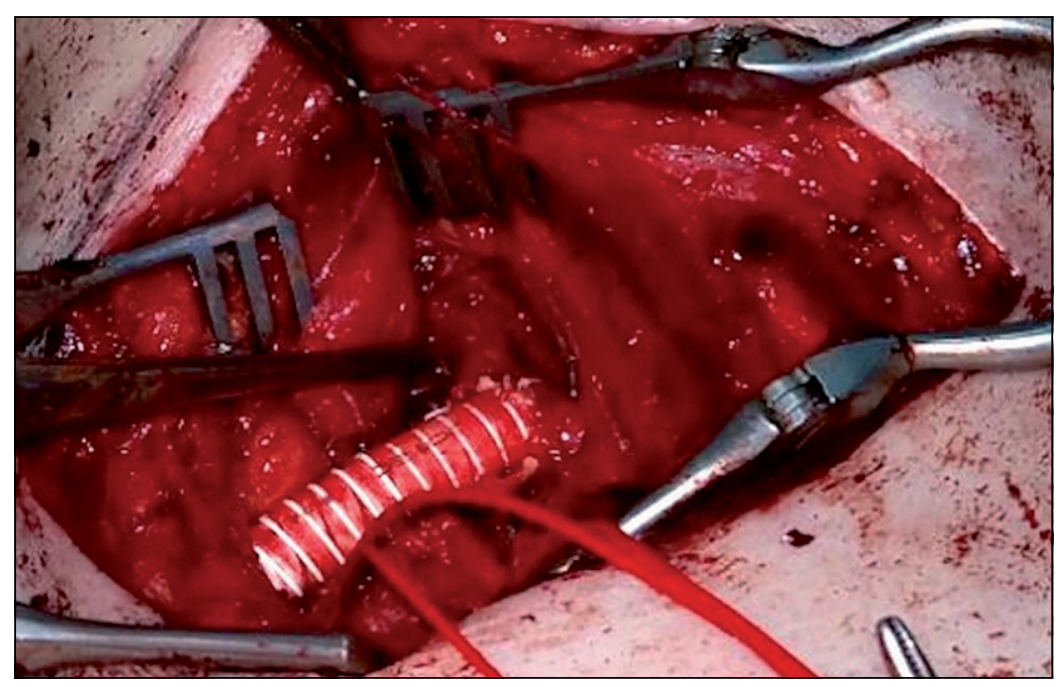

Figura 2. PTFE. Detalle intraoperatorio del injerto subclavio-axilar.

\section{Responsabilidades éticas}

Protección de personas y animales. Los autores declaran que para esta investigación no se han realizado experimentos en seres humanos ni en animales.

Confidencialidad de los datos. Los autores declaran que en este artículo no aparecen datos de pacientes.

Derecho a la privacidad y consentimiento informado. Los autores declaran que en este artículo no aparecen datos de pacientes.

\section{Conflicto de intereses}

Los autores declaran no tener ningún conflicto de intereses.

\section{Bibliografía}

1. Carnicero JA, Cano-Trigueros E, Baquer M, Arruabarrena A, Soguero I, Sesma
A, et al. Tratamiento quirúrgico del Síndrome del desfiladero torácico: nuestra experiencia (1986-2000). Angiología. 2002;54:29-37.
2. Shruti C, Ashutosh K. Usefulness of 3D $\mathrm{CT}$ in diagnosis of cervical rib presenting as supraclavicular swelling of short duration. J Clin DiagnRes. 2014;8:RD01-2. 